\title{
Evaluation of Respiratory Symptoms, Spirometric Lung Patterns and Metal Fume Concentrations among Welders in Indoor Air-Conditioned Building at Malaysia
}

\author{
Siti Farhana Zainal Bakri ${ }^{1,2^{*}}$, Azian Hariri ${ }^{2}$, Marzuki Ismail ${ }^{3}$, Samsuri \\ Abdullah $^{4}$, Nazrul Idzham Kassim ${ }^{1}$
}

\author{
${ }^{1}$ Faculty of Engineering and Technology, DRB-HICOM University of Automotive Malaysia, Pekan, 26607, \\ MALAYSIA \\ ${ }^{2}$ Faculty of Mechanical and Manufacturing Engineering, Universiti Tun Hussein Onn Malaysia, Batu Pahat, 86400, \\ MALAYSIA \\ ${ }^{3}$ School of Marine and Environmental Sciences, Universiti Malaysia Terengganu, Kuala Terengganu, 21300, \\ MALAYSIA \\ ${ }^{4}$ School of Ocean Engineering, Universiti Malaysia Terengganu, Kuala Terengganu, 21300, MALAYSIA
}

Received 1August 2018; Accepted 19 August 2018; Available online 30 October 2018

\begin{abstract}
Welding is one of the fundamental processes for metal joining in automotive industries and there is an increasing concern over occupational lung disease among welder due to exposure towards welding fumes. A lung disease questionnaire (ATS-DLD-78) was used to record the presence of respiratory symptoms among welders and in assessing lung function assessment, FEV1, FVC and FEV1/FVC are considered for identifying the lung condition; normal, obstructive or restrictive. The data were tabulated and subjected to logistic and multivariate analyses. Meanwhile, in order to trace metal in welders' body, this study utilized a non-invasive approach of toenail as a biomarker. Lung functions decrement was established in linear regression for FEV1 and FEV1/FVC respectively although not statistically significant. Analysis conducted revealed the presence of the following trace elements concentration in ascending sequence: $\mathrm{As}<\mathrm{Al}<\mathrm{Cu}<\mathrm{Mn}<\mathrm{Cr}<\mathrm{Ni}<\mathrm{Co}<\mathrm{Fe}$ (in the toenail) and $\mathrm{Co}<$ $\mathrm{Al}<\mathrm{Cu}<\mathrm{Ni}<\mathrm{As}<\mathrm{Cr}<\mathrm{Fe}<\mathrm{Mn}$ (in the cassette), respectively. The results validated the postulation that toenail metals composition shared a similar route of exposure with an anthropogenic source of activity. It is suggested a longer follow-up study is required to assess individual effects on lung function systems and the incidence of respiratory diseases among welders and this study indicates that toenail is a reliable biomarker of metal-workplace pollution and suitable for acquiring chronological information of welding fumes exposure.
\end{abstract}

Keywords: Respiratory symptoms, lung function, metal fume, welder, automotive, Malaysia.

\section{Introduction}

The local automotive industry has a positive significant impact on Malaysian socio-economic and despite current challenging economic scenario; it is forecasted that growth will continue in 2017 with number of employment in the automotive manufacturing to reach 27,000 personnel [1]. Apart from manufactured motor vehicles, passenger automobiles and light trucks, this sector also has partnered with the Army in assembles heavy truck for military i.e. armoured vehicles. A number of manpower is needed to cater to a variety of automotive manufacturing process. Welding is one of the fundamental processes for metal joining in automotive industries and there is an increasing concern over occupational lung disease among welder due to exposure towards welding fumes notably in a body shop area where the distance of worker is closed to the source [2] This process is often allied with respiratory symptoms as the fumes dispersed in air and inhalation is a common route of exposure to a welder where the movement of chest wall enables the expansion and shrinking of lung in human breathing mechanism [3], [4]. Key factors that affect the exposure towards welding fumes among welder are listed as a type of welding process; base metal and filler metals used; air movement; welding rod composition; work practices of welder; application of ventilation controls and location of weld-work take place either in indoor or outdoor [5].

The issue of welding health-related effects has been a controversial and much-disputed subject within the field of occupational safety and health in automotive industries. Aluminium, beryllium, cadmium oxides, copper, chromium, iron oxide, lead, manganese, nickel, molybdenum, zinc oxide and vanadium is a common metal found in the welding fume [6]. Irritation of eye, nose, throat, metal fume fever, nausea normally is related to acute exposure while systemic effects occurred from 
chronic exposure results in respiratory effects including decreased pulmonary function and occupational asthma [7], [8], [9]. The discharge of welding fumes from this anthropogenic activity into workplace surrounding air and enter into the body via inhalation and accumulated in various organs especially pulmonary systems had posed a risk to welders health due to its toxicity and long-term persistence. Welders at automotive industry have been shown to suffer from respiratory symptoms either chronic or welding related symptoms such as chest tightness, phlegm, dyspnea, wheezing, coughing or other respiratory symptoms whereas about half of welders experienced at least three of systemic symptoms while welding [10]. An assessment of heavy metals from welding fumes among welders population needs to be considered imperatively to evaluate the possible risk before any corrective and preventive action can be implemented. The evaluation of population exposure to pollution can be done by implementing bio-indicator as one of the tools. This biomarker able to deliver a current of body burden due to the accumulation of welding fumes either in recent or/and past occupational exposure. Recently, there has been a growing interest among researchers in respect of exploring human body samples literally on the application of toenail to investigate the heavy metals accumulation due to environmental pollution and/or occupational settings [11], [12], [13]. There have been a few studies associated with welding fume exposure in Malaysia. However, this study offers some important insight into the workplace area selected is beyond than normal practices as this is the only welding workplace that has been conducted indoors with the room is equipped with air-conditioner as Malaysian temperature is influenced geographically by tropical weather. The air-conditioner is installed in the welding area to prevent the hot crack occurrence as the special type of metal used is absolutely sensitive to hot temperature and low humidity. Therefore, the aim of this work is to study the prevalence of respiratory hazards and changes in pulmonary function among automotive industrial welders as well as to investigate the heavy metal levels in automotive welder's toenail, further seeking to evaluate and understand correlation with a number of parameters, incorporate to environmental workplace heavy-metal pollution.

\section{Method}

\subsection{Study Design and Setting}

This pilot study was conducted at one of the plants at Pekan Automotive Hub, Pahang, Malaysia in October 2016. There were 28 male welders working in airconditioned room participated in this study excluding practical trainees and all the selected welders had experienced at least more than one year experienced handling metal inert gases (MIG) welding. Out of 28 welders, four workers have been selected for metal fumes concentration study. All of the welders participated is Malay and majority speaks Bahasa Malaysia with a variety of dialect from East Coast of Malaysia. The company is involved in the manufacture, assembly, supply, refurbishment or retrofitting of military and commercial vehicles, equipment and spare parts. The $3600 \mathrm{~m}^{2}$ of welding workspace area is equipped with centralised air-conditioning system together with alarm systems to alert premise occupants once the concentration of dust or particulate matters upsurge. As the armoured plate is sensitive to environmental factors, the operation held in welding workspace is controlled in the range of temperature between $25^{\circ} \mathrm{C}-27^{\circ} \mathrm{C}$ with humidity range around $60 \% \mathrm{RH}$ in order to avoid any hydrogen crack. These welders had normal working hours, thus, the average exposure of workers to expose to contaminant without adverse effect over an average work shift is in $8 \mathrm{hr} /$ day or $40 \mathrm{hr} /$ week. It is compulsory for the welder to wear safety devices prior to entering to this workspace. An epidemiologic respiratory-related questionnaire was administered through a face-to-face interview before proceed with lung function test. This interview - analysis also considered on sociodemographic information, smoking habit and past work experience in the chemical hazardous environment. Body Mass Index (BMI, $\mathrm{kg} / \mathrm{m}^{2}$ ) was calculated based on height and weight measured among participants. Two types of smoking habits were categorised as never smoke and ever-smoker (current and former smokers). A former smoker is those who had smoked for at least one year but not during the last 12 months [14].

\subsection{Respiratory Questionnaire}

A lung disease questionnaire published by American Thoracic Society and the Division of Lung Diseases (ATS-DLD-78) was used to record the presence of respiratory symptoms among welders in the investigated plant. In overall, two main sections covered in the questionnaire: socio-demographic and respiratory problem. The socio-demographic information covered on the characteristics of age, gender, height, weight, marital status, race, education level, years of experience in welding job scope, types of welding used in the current and previous job and smoking habit included beerie (locally made cigarettes without filter commonly smoked in South East Asia) or hookah (local name for water-pipe or also known as shisha). The questionnaire was translated into Bahasa Malaysia (Malay language) and back-translated into English by applying forward and backwards translation respectively.

\subsection{Measurement of Lung Function}

A portable spirometer (Micro Medical DL, UK) was used to perform pulmonary function test by connected the handheld devices to spirometer software (Care Fusion, California) on a computer. A spirometry was performed with three acceptable spirograms in not more than eight trial once the devices have been calibrated with $3 \mathrm{~L}$ calibration syringe and the procedures for recording forced vital capacity follows according to American Thoracic Society (ATS) and European Respiratory Society (ERS) [15]. For safety reasons, sitting position 
with a nose clip in an arm-chair without wheels is preferable to avoid syncope [16]. In preparing the worker for testing before conducting spirometry, the welders are interviewed by a researcher to identify health conditions that may prevent the welder from safely performing maximal efforts in a spirometry test. In assessing of lung function, $\mathrm{FEV}_{1}, \mathrm{FVC}$ and $\mathrm{FEV}_{1} / \mathrm{FVC}$ are vital in identifying the conditions of lung either normal, obstructive or restrictive lung patterns [17]. An airflow obstruction may occur in references or predicted values as the ratio of $\mathrm{FEV}_{1}$ and $\mathrm{FEV}_{1} / \mathrm{FVC}$ is declined, and it is analysed and suggest as restrictive patterns when there is a reduction in lung volume, $\mathrm{FVC}$ or $\mathrm{FEV}_{1} / \mathrm{FVC}$ increased [18]. The measurement of lung function is suggested to conduct before the shift started whereas no exposure to welding fumes among welder on a working day [19]. The data interpretation from spirometry devices is using an established method that has been set based on predicted lung study among Indonesian population from Pneumobile Project Indonesia and the results are assessed for quality assurance [20].

\subsection{Sample Collection and Analysis}

A personal air pump Gillian 5000 (Sensidyne, USA) with three-piece sampling cassette (SKC Ltd, UK) equipped with $37 \mathrm{~mm} 0.8 \mu \mathrm{m}$ mixed cellulose ester (MCE) filter and supporting media has been attached to selected welders that represent welding points. The personal air pumps were calibrated before and after sampling by using TSI 4100 series pump calibrator (TSI Incorporated, USA), and the pump air flow was set to 1.7 $\mathrm{L} / \mathrm{min}$ flow rate. Cassette was attached within breathing zone area, in front of the face with 20 to $30 \mathrm{~cm}$ diameter from the nostrils. Meantime, a direct reading instrument of Dustrak (TSI Incorporated, USA) and Indoor Air Quality Meter IQ-410 (Graywolf Sensing Solutions, USA) are used for area monitoring to measure particulate matter (PM10), velocity, relative humidity and temperature. The instruments were located in the middle of the selected assembly line and a direct measurement during full working hours was done with one minute interval time. This research applied toenail as a noninvasive approach as it is easy to collect, and stored; convenient and practicable; reliable data; expressed a long-term exposure; more prevalent and preserved from any exogenous exposure; and slow growth rate [21]. Toenail samples were collected from all 10 toes of each subject by using stainless-steel nail clippers and stored in small envelopes together with an indication of toenail clipping date and staff identification code. Toenail clippings were analysed by following a modified version of Method 3050B, USEPA as described by Kile et al. [22] and Sanders et al. [23] in the past research where the samples then digested by an inductively coupled plasma mass spectrometry (ICP-MS) at the Central Laboratory, Universiti Malaysia Pahang. Thirteen elements were assessed: $\mathrm{Be}, \mathrm{Al}, \mathrm{Cr}, \mathrm{Mn}, \mathrm{Fe}, \mathrm{Co}, \mathrm{Ni}, \mathrm{Cu}, \mathrm{As}, \mathrm{Mo}, \mathrm{Ag}$, $\mathrm{Cd}$, and $\mathrm{Pb}$.

\subsection{Ethical Consideration}

Study approval was taken from a research ethics review committee of International Islamic University Malaysia, Pahang, Malaysia (Ref. ID: IREC 850). Verbal and written informed consent was taken from the participants.

\subsection{Statistical Analysis}

Data obtained from the questionnaire were entered into Epi Info ${ }^{\mathrm{TM}} 7$ provided by Centers for Disease Control and Prevention (CDC) and analysed using IBM SPSS Statistics version 23.0 for windows. Descriptive statistics were calculated for socio-demographic variables, lung volumes and respiratory symptoms. An analysis of total welding year, smoking status and current welding year in the automotive plant as predictor variables is run through binary logistic regression with the assumption of a cough, phlegm, wheeze and short breath as continuous variables. Despite, a logistic regression is then performed by entering predicted the percentage of lung volumes as dichotomous variables $\left(\mathrm{FEV}_{1}\right.$ and $\mathrm{FVC}$ with a value of $>80 \%$ vs $<80 \% ; \mathrm{FEV}_{1} / \mathrm{FVC}<70 \%$ vs $>70 \%$ ) to determine the crude odd ratio for respiratory symptoms. In determining the association of percentage predicted lung volumes with respiratory symptoms, a further study of Multiple Linear Regression (MLR) analysis is performed separately for $\mathrm{FEV}_{1}, \mathrm{FVC}$ and $\mathrm{FEV}_{1} / \mathrm{FVC}$ ratio. This assessment also takes into considerations of obstructive and restrictive lung patterns. Assessment of heavy metals concentration was calculated for arithmetic mean (AM), standard error (SE), standard deviation (SD), median, maximum, minimum, skewness and kurtosis values in order to represent the data in a readable and worthwhile form. The data was subjected and holds true with testing assumptions of normal distribution and covariance, thus Pearson correlation is employed for the relationship and association existed in the heavy metal measured [24]. A significant $\mathrm{p}$-value was considered when it less than 0.05 ( $p<0.05,95 \%$ Confidence Interval).

\section{Results and Discussion}

Frequencies of socio-demographic, welding types, welding years of experienced and lung function of welders' age in range 20 to 40 years are shown in Table 1. All participants are Malay and almost $75 \%$ of the participant is ever-smokers (current and ex-smoker) whilst $25 \%$ never smoke. From the questionnaire, it is recorded that in current workplace, all of the welders had used GMAW followed by $10.7 \%$ of welders applied SMAW and GTAW at the same work unit. The welding years at the company are varied among welder with maximum recorded is 13 years work experience as a welder in this organisation. Generally, 17 welders $(60.7 \%)$ in this company had previous experience in handling GMAW compared to SMAW, GTAW and FCAW with $42.9 \%, 21.4 \%$ and $10.7 \%$, respectively. 
Table 1: Socio-demographic, welding of exposure and lung function of the automotive male welders in the automotive industry.

\begin{tabular}{|c|c|c|c|}
\hline Variable & $\begin{array}{c}\text { Welder } \\
\text { n (\%) }\end{array}$ & Variable & $\begin{array}{l}\text { Mean } \\
( \pm \text { SD })\end{array}$ \\
\hline Below 29 years old & $18(64.3)$ & Height (m) & $1.69( \pm 0.05)$ \\
\hline $30-39$ years old & $9(32.1)$ & Weight $(\mathrm{kg})$ & $75.91( \pm 19.35)$ \\
\hline Above 40 years old & $1(3.6)$ & Welding year (previous job) & $2.80( \pm 3.38)$ \\
\hline Secondary education & $15(53.6)$ & Welding year (current job) & $3.53( \pm 3.14)$ \\
\hline Tertiary education & $13(46.4)$ & \multicolumn{2}{|c|}{$\begin{array}{l}\text { \% Predicted spirometric lung volumes in millimetres } \\
(\mathbf{N}=\mathbf{2 8})\end{array}$} \\
\hline Single & $14(50.0)$ & $\mathrm{FEV}_{1}^{2}$ & $86.71( \pm 12.75)$ \\
\hline Married & $14(50.0)$ & $\mathrm{FVC}^{3}$ & $83.39( \pm 12.62)$ \\
\hline Smoking Habit ${ }^{1}$ & & $\mathrm{FEV}_{1} / \mathrm{FVC}$ & $88.29( \pm 8.18)$ \\
\hline Never smoke & $7(25.0)$ & Lung Age (years) & $38.86( \pm 15.08)$ \\
\hline Former smoker & $1(3.6)$ & & \\
\hline Current smoker & $20(71.4)$ & & \\
\hline \multicolumn{4}{|c|}{ Types of welding used in the previous job } \\
\hline SMAW & $12(42.9)$ & & \\
\hline GMAW & $17(60.7)$ & & \\
\hline GTAW & $6(21.4)$ & & \\
\hline FCAW & $3(10.7)$ & & \\
\hline \multicolumn{4}{|c|}{ Types of welding used in the current job } \\
\hline SMAW & $3(10.7)$ & & \\
\hline GMAW & $28(100.0)$ & & \\
\hline GTAW & $3(10.7)$ & & \\
\hline FCAW & $0(0.0)$ & & \\
\hline
\end{tabular}

1. Smoking status defines as never, ever and former smoker of tobacco smoke, pipe smoke, cigars, shisha, beerie.

2. Forced expiratory volume in 1 second.

3. Forced vital capacity.

Phlegm is reported as a predominant type of respiratory complaint with $21.4 \%$ followed by a cough $(17.9 \%)$ and $14.3 \%$ was recorded for both shortness of breath and wheeze. The frequency of self-claimed and physician-diagnosed disease of bronchitis, pneumonia, chronic bronchitis, emphysema and asthma is shown in Table 2. There are no sign of bronchitis, pneumonia, chronic bronchitis were reported by the welders either self-reported or physician diagnose by medical doctors. The frequency of lung function patterns presents $60.71 \%$ of welders had a normal lung function followed by obstructive and restrictive with $3.57 \%$ and $35.71 \%$, respectively. There exists statistically significant difference for a cough $(\chi 2(3)=10.59, \mathrm{p}<0.05)$ than phlegm, wheeze and short breath symptoms by applying logistic regression model as shown in Table 3. The model explained Nagelkerke R2 of the variance of a $51.7 \%$ cough, $24.6 \%$ phlegm, $31.7 \%$ wheeze and $42.8 \%$ short breath with correctly classified $89.3 \%$ (a cough), $82.1 \%$ (phlegm), 92.9\% (wheeze and short breath) for the case, respectively.

The full model containing all predictors for a total years welding, smoking status and current welding years in this investigated automotive plant, Pekan as in Table 3 indicating that the model was able to distinguish between respondents who reported and did not report on the existence of a cough, phlegm, wheeze and short breath. Direct logistic regression was performed in assessing the influence of a number of factors that respondents would report that they had a problem with their respiratory systems. The model contained three dependent variables $\left(\mathrm{FEV}_{1}, \mathrm{FVC}\right.$ and $\left.\mathrm{FEV}_{1} / \mathrm{FVC}\right)$. The full model containing all predictors for a cough, phlegm, wheeze and short breathe as in Table 3 indicating that the model was able to distinguish between respondents who reported and did not report on the existence of the respiratory problem. In univariate logistic regression, as shown in Table 3, there is no significant decrement of $\mathrm{FEV}_{1}, \mathrm{FVC}$ and $\mathrm{FEV}_{1} / \mathrm{FVC}$. However, the strongest predictor of $\mathrm{FEV}_{1}$, $\mathrm{FVC}$ and $\mathrm{FEV}_{1} / \mathrm{FVC}$ was a cough and phlegm by recording an odds ratio of $6.62,4.27$ and 0.04 respectively. This indicated that respondents who had $\mathrm{FEV}_{1}(>80 \%)$ had 6 times likely for a cough; FVC ( $>$ $80 \%$ ) had 4 times likely to have phlegm than those who had $\mathrm{FEV}_{1}$ and FVC less than $80 \%$. The odds ratio of 0.04 for $\mathrm{FEV}_{1} / \mathrm{FVC}$ was less than 1 , indicating that for any value capture on the increasing prediction percentage more than $70 \%$ were 0.04 times less likely to report having a cough, controlling for other factors in the model. As this case study is focused on the small sample and has a small subject per variable, the adjusted R-square is preferred rather than the conventional $\mathrm{R}$ - square value for quantifying the proportion of variance explained by the model [25]. Adjusted R square (R2adj) and ANOVA (p) for respiratory symptoms and percentage predicted lung volumes for $\mathrm{FEV}_{1}(\mathrm{R} 2 \mathrm{adj}=0.09 ; \mathrm{p}=0.20)$; FVC (R2adj $=-0.05 ; \mathrm{p}=0.63) ; \mathrm{FEV}_{1} / \mathrm{FVC}(\mathrm{R} 2 \mathrm{adj}=0.17 ; \mathrm{p}=0.09)$. Apart from that, Analysis of Variance (ANOVA) shows no significant values of independent variables and 
percentage prediction lung volumes with evaluated $\mathrm{p}$ value more than $0.05(\mathrm{p}>0.05)$. The comparing of the contribution of each independent variable is tabulated in Table 4

Table 2: Frequency of respiratory symptoms, asthma and lung function among welder population in Pekan Automotive plant, Malaysia.

\begin{tabular}{|c|c|c|}
\hline Prevalence of respiratory symptoms (Total sample $\mathbf{N}=\mathbf{2 8}$ ) & $\mathbf{n}$ & $(\%)$ \\
\hline Cough $^{4}$ & 5 & 17.9 \\
\hline Phlegm 5 & 6 & 21.4 \\
\hline Shortness of breath ${ }^{6}$ & 4 & 14.3 \\
\hline Wheeze ${ }^{7}$ & 4 & 14.3 \\
\hline Self-reported emphysema & 1 & 3.6 \\
\hline Physician diagnose emphysema & 1 & 3.6 \\
\hline Self-reported asthma & 4 & 14.3 \\
\hline Physician diagnose asthma & 3 & 10.7 \\
\hline \multicolumn{3}{|l|}{ The frequency of lung function patterns (Total sample $N=28$ ) } \\
\hline Normal $^{8}$ & 17 & 60.71 \\
\hline Obstructive $^{9}$ & 1 & 3.57 \\
\hline Restrictive $^{10}$ & 10 & 35.71 \\
\hline 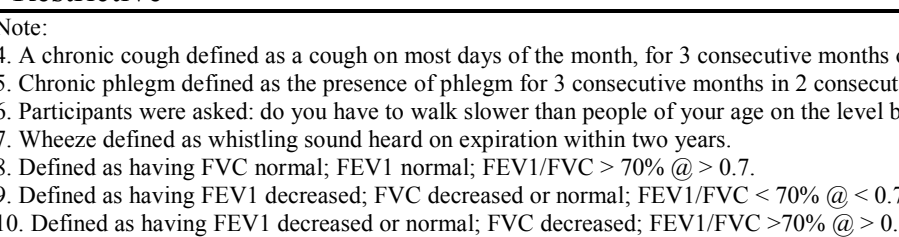 & & \\
\hline
\end{tabular}

The highest value recorded for beta standardise coefficient of $\mathrm{FEV}_{1}, \mathrm{FVC}$ and $\mathrm{FEV}_{1} / \mathrm{FVC}$ are wheeze (0.40), short breath (0.25) and wheeze (0.56), respectively. The highest value recorded (by ignoring any negative signs out the front) interpreted that wheeze makes the strongest unique contribution to explaining $\mathrm{FEV}_{1}$ and $\mathrm{FEV}_{1} / \mathrm{FVC}$ whilst short breath makes the strongest contribution for FVC. This is due to fewer values of beta indicate a less of a unique contribution. A lung functions decrement was found in linear regression for both $\mathrm{FEV}_{1}$ and $\mathrm{FEV}_{1} / \mathrm{FVC}$ except on $\mathrm{FVC}$ but not statistically significant $(\mathrm{p}>0.05)$. This study is considered as one of the pioneering research on the application of respiratory questionnaire ATS-DLD-78A in a local language (Bahasa Malaysia) among automotive welders in Malaysia. The forced expiratory volume in 1s $\left(\mathrm{FEV}_{1}\right)$, forced vital capacity $(\mathrm{FVC}), \mathrm{FEV}_{1} / \mathrm{FVC}$, and expiratory flow rates in 28 welders were investigated. This research also exercised on the current exposure to respirable particles, working conditions and protective measures at current and former workplaces. In contrast to earlier findings, however, no evidence of the correlation between respiratory symptoms and lung function test is found. Surprisingly, from an overall research study, the respiratory symptoms of a cough, phlegm, wheeze and short breath are not statistically significant $(\mathrm{P}>0.05)$ with the decrement of lung function volumes $\left(\mathrm{FEV}_{1}, \mathrm{FVC}\right.$ and $\mathrm{FEV}_{1} / \mathrm{FVC}$ ). The findings are not aligned as the study is focused on a small sample size than the previous study with sample $\mathrm{N}=200$ [26]. Despite there are less significant shows in the model, still, in the logistic regression, shows that a cough and phlegm as the strongest predictors of $\mathrm{FEV}_{1}$ and $\mathrm{FEV}_{1} / \mathrm{FVC}$. Previous research has indicated that a cough and phlegm indicators have a positive impact on obstructive lung patterns [27]. In contrast to Hasnain et al., the result from this study is in the same vein as previous researchers that have found a major restrictive lung pattern among welders than obstructive disorder [28], [29], [30].

A specific occupational exposure to vapours, gases, dust and fumes may interfere the worker's respiratory systems but however, in this pilot study, the symptoms identified by questionnaires is not successfully predicted the impaired lung function which was verified by spirometry [31]. The main factors that contribute to the less precision and statistical insignificance of results obtained are the size of the study population which in this research the scope of the sample is small $(\mathrm{N}=28)$. Skelly (2011) have been identified sample size as one of the inter-related factors of statistical significance by which the larger the sample sizes, the likely the statistical significance is to be seen and enhanced due to random error and variability are decrease [32]. In this case, welding gases cause restriction while smoking may cause obstruction. It is clear that the lung decrements among welders are influenced by welding fumes as $35.71 \%$ of welders identified to have the restrictive disorder. In this study, the prevalence of physician-diagnosed and selfreported respiratory illness is observed and recorded for bronchitis, pneumonia, chronic bronchitis, emphysema and asthma. There are none of the respondents claimed to have respiratory problems associated with bronchitis, pneumonia and chronic bronchitis. The prevalence recorded for physician-diagnosed and self-reported is only applicable for emphysema with $3.6 \%$ for both diagnosed, and asthma as $10.7 \%$ and $14.3 \%$ respectively. In an analysis of global asthma prevalence in adults, To et al., (2012) noted that doctor-diagnosed asthma, clinical 
asthma and wheezing symptoms in Malaysia is 5.21\%, $5.51 \%$ and $7.55 \%$, respectively [33]. However, there is a paucity of representative data regarding the prevalence of emphysema in Malaysia. In this study, the selected population was exposed to welding fumes from occupational settings and there is a large volume of published studies describing the role of prolonged exposure to chemical constituents of welding fumes is being increasingly recognised to affect the lung function [14],[20],[34].

Table 3: Logistic regression analysis of respiratory symptoms with predictor variables and spirometric lung function patterns among welders at Pekan Automotive Hub, Malaysia.

\begin{tabular}{|c|c|c|c|c|c|}
\hline \multirow{2}{*}{$\begin{array}{l}\text { Respiratory } \\
\text { symptoms with } \\
\text { predictor variable. }\end{array}$} & Crude OR & \multirow[b]{2}{*}{$p$} & \multirow{2}{*}{$\begin{array}{l}\text { Respiratory } \\
\text { symptoms with } \\
\text { spirometric lung } \\
\text { function patterns }\end{array}$} & \multirow{2}{*}{$\begin{array}{l}\text { Crude OR } \\
(95.0 \% \mathrm{CI})\end{array}$} & \multirow[b]{2}{*}{$p$} \\
\hline & $(95.0 \% \mathrm{CI})$ & & & & \\
\hline A cough & & & \multicolumn{3}{|c|}{$\%$ Predicted FEV 1 volume } \\
\hline Total welding years & $1.43(0.73-2.81)$ & 0.300 & Cough & $6.62(0.45-97.35)$ & 0.170 \\
\hline Smoking status & $5.12 \mathrm{E}+11(0.00)$ & 0.990 & \multirow{2}{*}{$\begin{array}{l}\text { Phlegm } \\
\text { Wheeze }\end{array}$} & $1.98(0.17-23.36)$ & 0.590 \\
\hline $\begin{array}{l}\text { Welding years } \\
\text { (current) }\end{array}$ & $0.28(0.05-1.55)$ & 0.150 & & $2.90(0.12-67.70)$ & 0.510 \\
\hline Phlegm & & & \multirow{2}{*}{\multicolumn{2}{|c|}{$\begin{array}{l}\text { Short Breath } \\
\text { \% Predicted FVC volume }\end{array}$}} & 1.000 \\
\hline Total welding years & $0.97(0.71-1.36)$ & 0.930 & & & \\
\hline Smoking status & $9.36 \mathrm{E}+8(0.00)$ & 0.990 & Cough & $2.97(0.22-39.55)$ & 0.410 \\
\hline $\begin{array}{l}\text { Welding years } \\
\text { (current) }\end{array}$ & $0.86(0.47-1.58)$ & 0.630 & Phlegm & $4.27(0.36-50.68)$ & 0.250 \\
\hline Wheeze & & & Wheeze & $2.17(0.13-36.15)$ & 0.590 \\
\hline Total welding years & $1.16(0.80-1.68)$ & 0.430 & Short Breath & $0.07(0.00-3.05)$ & 0.170 \\
\hline Smoking status & $0.32(0.02-4.24)$ & 0.390 & \multicolumn{3}{|c|}{$\%$ Predicted $\mathrm{FEV}_{1} / \mathrm{FVC}$ volume } \\
\hline $\begin{array}{l}\text { Welding years } \\
\text { (current) }\end{array}$ & $0.61(0.33-1.13)$ & 0.120 & Cough & $0.04(0.00)$ & 1.000 \\
\hline Short Breath & & & Phlegm & $1.63 \mathrm{E}+15(0.00)$ & 1.000 \\
\hline Total welding years & $1.29(0.83-2.00)$ & 0.230 & Wheeze & $3.17 \mathrm{E}+15(0.00)$ & 1.000 \\
\hline Smoking status & $4.85(0.04-610.01)$ & 0.520 & Short Breath & - & 1.000 \\
\hline $\begin{array}{l}\text { Welding years } \\
\text { (current) }\end{array}$ & $0.47(0.21-1.02)$ & 0.060 & & & \\
\hline
\end{tabular}

A further research is warranted to explore such associations and this study was not powered to detect the risk factors associated with respiratory symptoms due to limited sample size. A few limitations of this study need to be considered as it is difficult to establish a causal association between deterioration of lung function and respiratory symptoms due to its nature cross-sectional study. Even though this was a small sample size pilot study, the consistency of lung volume decrement, especially on $\mathrm{FEV}_{1}$ and $\mathrm{FEV}_{1} / \mathrm{FVC}$, may provide the baseline for further research on welding exposure at automotive industries. As a preliminary research, the validity of ATS respiratory questionnaire is proposed to be used and to compare with the spirometric patterns in a large sample size since spirometry able to identify impaired lung function among welders although the respondents did not have manifest the symptoms in the respiratory questionnaire.

From the results findings, there is low (zero per cent) of sensitivity recorded and positive predictive value compared to high readings of specificity and negative predictive values for all symptoms as in the ATS questionnaire. This indicates the consistency of research findings with the previous study that reported the low sensitivity and high specificity [26], [35]. The results of a physical environmental parameter of velocity, humidity, temperature and dust (PM10) from area monitoring of four workstations are tabulated in Table 5. The temperature and relative humidity in working area are maintained in range $26{ }^{\circ} \mathrm{C}$ to $27{ }^{\circ} \mathrm{C}$ with humidity range $63 \% \mathrm{RH}$ to $67 \% \mathrm{RH}$ respectively to preserve the body-inwhite of armour vehicles from the hot crack. The results of dust found in all welding point show a small range with a maximum mean of dust recorded is during the evening.

Apart from that, the result obtained from a measurement of personal sampling that has been attached to workers with the sampling head within the breathing zone is shown in Table 6 . The concentration of selected metal from four different welding points had shown that all concentrations except aluminium had exceeded the safe level allowed by USECHH Regulations 2000. This suggests an immediate attention need to reduce the concentration of metal fumes and respirable dust through the hierarchy of control specifically in engineering control for adequate ventilation in the welding room as the welding activities are performed in indoor air building. 
International Journal of Integrated Engineering: Special issue 2018:

Mechanical Engineering, Vol. 10 No. 5 (2018) p. 109-121

(C) Penerbit UTHM

DOI: https://doi.org/10.30880/ijie.xx.xx.xxxx.xx.xxxx

Table 4: Multiple Linear Regression analysis of respiratory symptoms with percentage predicted lung volumes among welders at Pekan Automotive Hub, Malaysia.

\begin{tabular}{lcc}
\hline & Beta Coefficient $(95.0 \% \mathrm{CI})$ & $\boldsymbol{p}$ \\
\hline \% Predicted FEV $\mathbf{1}_{\mathbf{1}}$ volume & & \\
Cough & $0.02(-13.84-15.14)$ & 0.930 \\
Phlegm & $0.20(-7.45-19.47)$ & 0.370 \\
Wheeze & $0.40(-0.99-29.92)$ & 0.070 \\
Short Breath & $-0.39(-29.80-2.09)$ & 0.090 \\
\% Predicted FVC volume & & \\
Cough & $0.13(-11.15-19.69)$ & 0.570 \\
Phlegm & $0.22(-7.82-20.82)$ & 0.360 \\
Wheeze & $0.11(-12.54-20.35)$ & 0.630 \\
Short Breath & $-0.25(-25.70-8.24)$ & 0.300 \\
\% Predicted FEV $\mathbf{~}_{\mathbf{1} \text { FVC volume }}$ & & \\
Cough & $-0.12(-11.49-6.31)$ & 0.550 \\
Phlegm & $-0.06(-9.44-7.09)$ & 0.770 \\
Wheeze & $0.56(3.47-22.45)$ & 0.010 \\
Short Breath & $-0.25(-15.54-4.05)$ & 0.240 \\
\hline
\end{tabular}

The overall statistics for heavy metal concentrations in the analysed toenail samples are shown in Table 7. Out of 13 heavy metals targeted, a total of 8 metals were detected in both toenail specimens and cassettes from personal air sampling that were analysed by ICP-MS. In the analysed samples, there is no $\mathrm{Be}, \mathrm{Mo}, \mathrm{Ag}, \mathrm{Cd}$ and $\mathrm{Pb}$ were detected in both samples, while the other metals show concentration in the following order: $\mathrm{As}<\mathrm{Al}<\mathrm{Cu}$ $<\mathrm{Mn}<\mathrm{Cr}<\mathrm{Ni}<\mathrm{Co}<\mathrm{Fe}$ (in the toenail) and $\mathrm{Co}<\mathrm{Al}<$ $\mathrm{Cu}<\mathrm{Ni}<\mathrm{As}<\mathrm{Cr}<\mathrm{Fe}<\mathrm{Mn}$ (in the cassette) respectively. The heavy metals in toenail samples show a broad range of concentrations and this is shown in large standard deviations and significant difference between the minimum and maximum values in Table 7 .
Table 5: Physical environmental reading from workplace monitoring.

\begin{tabular}{lcccc}
\hline \multirow{2}{*}{$\begin{array}{l}\text { Environmental } \\
\text { Parameter }\end{array}$} & $\begin{array}{c}\mathbf{9 . 0 0} \\
\mathbf{a m}\end{array}$ & $\begin{array}{c}\mathbf{1 1 . 0 0} \\
\mathbf{a m}\end{array}$ & $\begin{array}{c}\mathbf{2 . 0 0} \\
\mathbf{p m}\end{array}$ & $\begin{array}{c}\mathbf{4 . 0 0} \\
\mathbf{p m}\end{array}$ \\
\hline Velocity $(\mathrm{m} / \mathrm{s})$ & 0.07 & 0.96 & 0.48 & 0.40 \\
Temperature & 26.63 & 26.97 & 27.32 & 27.80 \\
$\left({ }^{\circ} \mathrm{C}\right)$ & & & & \\
$\begin{array}{l}\text { Humidity } \\
(\% \mathrm{RH})\end{array}$ & 67.36 & 65.32 & 63.38 & 65.25 \\
$\mathrm{PM} 10\left(\mathrm{mg} / \mathrm{m}^{3}\right)$ & 6.93 & 7.39 & 7.10 & 7.48 \\
\hline
\end{tabular}

Table 6: Comparison of metal concentration found in cassette samples with Use and Standards of Exposure of Chemicals Hazardous to Health (USECHH) Regulations 2000 at four different breathing zones.

\begin{tabular}{|c|c|c|c|c|c|}
\hline \multirow{2}{*}{ Trace metal } & \multicolumn{4}{|c|}{ Welding Point Mean Concentration $\left(\mathrm{mg} / \mathrm{m}^{3}\right)$} & \multirow{2}{*}{$\begin{array}{l}\text { PEL USECHH Regulations } \\
2000\left(\mathrm{mg} / \mathrm{m}^{3}\right)\end{array}$} \\
\hline & A & B & $\mathrm{C}$ & D & \\
\hline $\mathrm{Al}$ & 1.655 & 1.028 & 1.324 & 1.545 & 5.00 \\
\hline $\mathrm{Cr}$ & 220.106 & 158.434 & 15.737 & 12.547 & 0.50 \\
\hline $\mathrm{Mn}$ & 920.577 & 5072.946 & 2316.609 & 2121.348 & 0.20 \\
\hline $\mathrm{Fe}$ & 3719.117 & 755.107 & 1792.522 & 1393.042 & 5.00 \\
\hline Co & 0.127 & $\mathrm{BDL}$ & BDL & BDL & 0.10 \\
\hline $\mathrm{Ni}$ & 98.662 & 59.293 & 39.849 & 27.366 & 1.50 \\
\hline $\mathrm{Cu}$ & 31.448 & 18.453 & 6.498 & 3.899 & 0.20 \\
\hline As & 296.624 & 18.079 & 0.422 & 0.042 & 0.01 \\
\hline
\end{tabular}

Notes: Abbreviation: PEL: Permissible Exposure Limits; BDL: below the detection limit (less than 0.5ppb)

In the present study, the greatest concentration of seven out of eight heavy metals traced in welders toenail was found and had recorded the highest value of aluminium, chromium, manganese, iron, nickel, copper

and arsenic in the active smoker of 26-year-old welder that have 7 years working experience as welders in automotive industries with concentration recorded of
$47.40 \mu \mathrm{g} / \mathrm{g}(\mathrm{Al}), 58.20 \mu \mathrm{g} / \mathrm{g}(\mathrm{Cr}), 65.60 \mu \mathrm{g} / \mathrm{g}(\mathrm{Mn})$, $2102.90 \mu \mathrm{g} / \mathrm{g}(\mathrm{Fe}), 55.20 \mu \mathrm{g} / \mathrm{g}(\mathrm{Ni}), 26.10 \mu \mathrm{g} / \mathrm{g}(\mathrm{Cu})$ and $0.582 \mu \mathrm{g} / \mathrm{g}$ (As) respectively. Generally, the concentration of aluminium, iron, cobalt, nickel and copper were found higher in welder's toenail than in cassette. The studies presented thus far provide evidence that arsenic is emitted from welding activities [36], [37]. It has been suggested that the presence of arsenic in 
workers body is also dependent on seafood intake especially marine fish and smoking habit [38]. Mok et al. [39] found that the level of arsenic in Malaysia aquaculture food product was elevated but the level of contaminants has not exceeded the level set by the Joint FAO/WHO Expert Committee on Food Additives (JECFA). In 2005, a few researchers have reported that toenail arsenic is significantly higher among individuals that consume drinking water especially from a tube well and/or groundwater that known to have a high concentration of arsenic [40], [41]. A various health problem may burden workers from a chronic exposure to arsenic such as bladder cancer, renal disease, skin, lung, and liver [42], [43].

Table 7: Summary statistics of heavy metal concentration in welder's toenail specimen $(\mu \mathrm{g} / \mathrm{g})$.

\begin{tabular}{lcccccccc}
\hline Heavy metal & $\mathbf{A M}$ & SE & SD & Med & Min & Max & Skewness & Kurtosis \\
\hline $\mathrm{Al}_{\text {Toenail }}$ & 17.575 & 10.310 & 20.620 & 10.750 & 1.40 & 47.40 & 1.599 & 2.602 \\
$\mathrm{Cr}_{\text {Toenail }}$ & 19.896 & 19.155 & 33.177 & 1.30 & 0.188 & 58.20 & 1.730 & - \\
$\mathrm{Mn}_{\text {Toenail }}$ & 18.323 & 15.813 & 31.626 & 3.750 & 0.192 & 65.60 & 1.960 & 3.858 \\
$\mathrm{Fe}_{\text {Toenail }}$ & 2102.9 & - & - & 2102.9 & 2102.9 & 2102.9 & - & - \\
$\mathrm{Co}_{\text {Toenail }}$ & 46.70 & - & - & 46.70 & 46.70 & 46.70 & - & - \\
$\mathrm{Ni}_{\text {Toenail }}$ & 21.733 & 16.961 & 29.378 & 9.80 & 0.20 & 55.20 & 1.526 & - \\
$\mathrm{Cu}_{\text {Toenail }}$ & 13.221 & 12.879 & 18.214 & 13.221 & 0.342 & 26.10 & - & - \\
$\mathrm{As}_{\text {Toenail }}$ & 0.582 & - & - & 0.582 & 0.582 & 0.582 & - & - \\
\hline
\end{tabular}

Notes: Abbreviation: AM: Arithmetic mean, SE: Standard Error of Mean, SD: Standard Deviation

Table 8: Correlation matrix for welder's toenail samples giving values of Pearson correlation coefficients for pairs of heavy metals.

\begin{tabular}{ccccccccc}
\hline & $\mathbf{A l}$ & $\mathbf{C r}$ & $\mathbf{M n}$ & $\mathbf{F e}$ & $\mathbf{C o}$ & $\mathbf{N i}$ & $\mathbf{C u}$ & $\mathbf{A s}$ \\
\hline $\mathbf{A l}$ & 1 & & & & & & & \\
$\mathbf{C r}$ & 0.986 & 1 & & & & & & \\
$\mathbf{M n}$ & $0.982^{*}$ & $0.999^{*}$ & 1 & & & & & \\
$\mathbf{F e}$ & $\mathrm{b}$ & $\mathrm{b}$ & $\mathrm{b}$ & 1 & & & \\
$\mathbf{C o}$ & $\mathrm{b}$ & $\mathrm{b}$ & $\mathrm{b}$ & $\mathrm{b}$ & 1 & & & \\
$\mathbf{N i}$ & 0.940 & 0.984 & 0.973 & $\mathrm{~b}$ & $\mathrm{~b}$ & 1 & & \\
$\mathbf{C u}$ & $1.00^{* *}$ & $1.00^{* *}$ & $1.00^{* *}$ & $\mathrm{~b}$ & $\mathrm{~b}$ & $1.00^{* *}$ & 1 & \\
$\mathbf{A s}$ & $\mathrm{b}$ & $\mathrm{b}$ & $\mathrm{b}$ & $\mathrm{b}$ & $\mathrm{b}$ & $\mathrm{b}$ & $\mathrm{b}$ & 1 \\
\hline
\end{tabular}

Notes:* Correlation is significant at the 0.05 level (2-tailed), **: Correlation is significant at the 0.01 level (2-tailed) and b: Cannot be computed because at least one of the variables is constant.

Chromium hexavalent compounds ( $\mathrm{Cr}$ VI) are known carcinogens and the study on the emission of welding fumes that contained this metal had shown that this metal accumulated in welder's lung and may promote to lung tumours [44], [45]. The lowest concentration $(0.399 \mathrm{mg} / \mathrm{m} 3)$ was found in the active smoker of a 40 year-old male who has worked for 19 years as a welder in the automotive body shop area. An occupational exposure to chromium to the worker is recognised to cause a multiorgan damage including asthma, kidney problems, respiratory and pulmonary disease [46]. The existence of toxical manganese $(\mathrm{Mn})$ in welding fumes play the main role for the neuro-behaviour disorder as the brain is the target organ of manganese toxicity and the inhalation exposure of airborne manganese is common among welders [47], [48]. Some of the researchers identified manganese as neurotoxic metal [13]. The previous study in China had revealed a significant correlation on exposure dosage of welding rod with manganese level found among welders [49]. The concentration of manganese in the studied toenail was found to be higher with the reported values of manganese in welders toenail by Hassani et al. [13] with a mean of $3.08 \mu \mathrm{g} / \mathrm{g}$.
Meanwhile, Laohaudomchok et al. [50] reported manganese concentration in welders to toenail in the range of 0.05 to $10.41 \mu \mathrm{g} / \mathrm{g}$, being lower with the finding range of this study. Apart from the fact that the manganese was mostly emitted through welding and various occupational setting, the manganese also can be found in surface soil, groundwater, drinking water, and the accumulation of this metal in terrestrial and aquatic food chain had exposed the elevated of manganese concentration in the human body including in toenail [12], [51], [52]. A chronic effect from a prolonged exposure to manganese toxicity specifically through the industrial common route of exposure (inhalation) may potentially lead to mental disorder and neurotoxicity issues that mainly relates to the damage of central nervous system.

The trace metal of aluminium found in welders toenail sample show moderate quantities where the lowest concentration of aluminium $(1.40 \mu \mathrm{g} / \mathrm{g})$ was found in an ever-smoker young male age 23 -year-old with three years of welding experience in the industry. In 1978, Chen et al. [53] published a case study paper in which they described a pulmonary granulomatosis that associates with inhalation of aluminium dust in the 31year-old white male. As noted by Polizzi et al. [54] a 
submicron-sized of suspended aluminium particles generated by welding activities tend to accumulate in the lungs and is easily penetrate into alveoli through inhalation due to its fine particles. This mechanism had triggered the most respiratory problems among welders other than neurological symptoms such as Alzheimer
[55]. Data from the previous source also had identified the existence of aluminium was associated with the problem on reproductive systems as this element is one of the most abundant metal in the world [56], [57].

Table 9: Pearson correlation matrix of welder's toenail sample $(\mu \mathrm{g} / \mathrm{g})$ and heavy metals captured in the cassette (mg/m3).

\begin{tabular}{|c|c|c|c|c|c|c|c|c|c|}
\hline \multirow{10}{*}{ 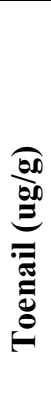 } & \multirow[b]{3}{*}{$\mathrm{Al}$} & \multicolumn{8}{|c|}{ Cassette $\left(\mathrm{mg} / \mathrm{m}^{3}\right)$} \\
\hline & & $\mathrm{Al}$ & $\mathrm{Cr}$ & $\mathrm{Mn}$ & $\mathrm{Fe}$ & $\mathrm{Co}$ & $\mathrm{Ni}$ & $\mathrm{Cu}$ & As \\
\hline & & -0.078 & -0.322 & -0.207 & 0.153 & $\mathrm{~b}$ & -0.092 & -0.203 & -0.115 \\
\hline & $\mathrm{Cr}$ & -0.015 & -0.951 & -0.202 & -0.154 & $\mathrm{~b}$ & -0.743 & -0.845 & -0.531 \\
\hline & $\mathrm{Mn}$ & -0.114 & -0.490 & -0.159 & 0.013 & $\mathrm{~b}$ & -0.277 & -0.383 & -0.281 \\
\hline & $\mathrm{Fe}$ & $\mathrm{b}$ & $\mathrm{b}$ & $\mathrm{b}$ & $\mathrm{b}$ & $\mathrm{b}$ & $\mathrm{b}$ & $\mathrm{b}$ & $\mathrm{b}$ \\
\hline & $\mathrm{Co}$ & $\mathrm{b}$ & $\mathrm{b}$ & $\mathrm{b}$ & $\mathrm{b}$ & b & $\mathrm{b}$ & $\mathrm{b}$ & $\mathrm{b}$ \\
\hline & $\mathrm{Ni}$ & -0.195 & -0.991 & -0.023 & -0.329 & $\mathrm{~b}$ & -0.851 & -0.927 & -0.675 \\
\hline & $\mathrm{Cu}$ & $1.00 * *$ & $-1.00 * *$ & $-1.00 * *$ & $1.00 * *$ & b & $-1.00 * *$ & $-1.00 * *$ & $-1.00 * *$ \\
\hline & As & $\mathrm{b}$ & $\mathrm{b}$ & $\mathrm{b}$ & $\mathrm{b}$ & $\mathrm{b}$ & $\mathrm{b}$ & $\mathrm{b}$ & $\mathrm{b}$ \\
\hline
\end{tabular}
variables is constant.

A strong evidence of nickel was found in this study with minimum concentration recorded in toenail is 0.20 $\mu \mathrm{g} / \mathrm{g}$ in 38-years-old male welder who never smoke and had 10 years of welding experience in the automotive industry. In an analysis of metal fumes from welding exposure, Grashow et al. [58] found the element of nickel is the highest concentration in toenail samples compared to lead, manganese, cadmium and arsenic with detection limit recorded is $0.019 \mu \mathrm{g} / \mathrm{g}$. Meanwhile, Wong et al. [59] had reported that the mean concentration of nickel in welder's toenail is $8.14 \mu \mathrm{g} / \mathrm{g}$, which is slightly lower than this study. Same as the other fine and ultrafine metal fumes such as manganese and chromium, the emission of nickel from welding activities is also known to be toxic [60]. A prolonged exposure to nickel may damage liver and heart, problems in the respiratory tract, decreased weight and cause skin irritation, physiological interference as well as cardiovascular disease [61], [62], [63], [64]. Previous research has indicated that lung and kidney have been identified as the main target organ of nickel accumulation [65].

In the studied toenail, iron (Fe) existed practically in one sample with concentration recorded is $2102.90 \mu \mathrm{g} / \mathrm{g}$ obtained from an active smoker welder. The concentration of iron in this analysed toenail samples was higher than Nigerian male iron welder's toenail sample with a range concentration is $27.43 \mu \mathrm{g} / \mathrm{g}$ to $45.00 \mu \mathrm{g} / \mathrm{g}$. Even though iron is one of the essential metals in life, the toxicological consideration is crucial especially in the case of iron overloaded. Accumulation of iron in the lungs may localize the occurrence of siderosis, silicosis, lung tissue damage, cancer, benign pneumoconiosis and decrement of lung function as well as other serious adverse health effects to liver, heart, immune systems since the chronic iron toxicity is a common problem in adults [66], [67]. Among the toenail specimen, the concentration of copper $(\mathrm{Cu})$ was traced in two respondents in age 26 and 40 years old and both are an active smoker with at least seven years of industrial welding experience. This result is slightly higher than the copper recorded in welders toenail with a range of concentration between $1.66 \mu \mathrm{g} / \mathrm{g}$ to $4.00 \mu \mathrm{g} / \mathrm{g}$ [61]. Concurrently, the concentration of cobalt $(\mathrm{Co})$ is only traced to non-smoker welder who had worked for almost two decades as a welder. According to the Public Health Statement for Cobalt released by Agency for Toxic Substances and Disease Registry (ATSDR), the exposure of human and animals to cobalt found in environment is basically not harmful, however, if the level of element taken into human body is exceed the levels, it may contribute to harmful health effects such as asthma, pneumonia, skin rashes, wheezing and so forth [68].

Apparently, there is no value recorded for beryllium (Be), molybdenum (Mo), silver (Ag), cadmium (Cd) and lead $(\mathrm{Pb})$ in both toenail and cassette samples as the traced metal is below the detection limit of analysis (below $0.5 \mathrm{ppb}$ ). The association degree and linear relationship of a metal traced element in welder's toenail specimen were measured by means of Pearson's correlation analysis and the results are presented in Table 8. This statistical evidence had suggested that the existence of metals in the toenail had a similar anthropogenic source of activity and there are strong significant correlations of toenail metal concentration with one another, with the exception of arsenic, iron and cobalt. Conversely, in observing the association on heavy metals found in toenail with the samples from personal monitoring, the results as in Table 9 had shown a very weak negative correlation which indicates that the anthropogenic source of origin of metal in toenail does not correlate with the workplace welding fumes emission and this might due to antagonism of pairing metals absorption in welders toenail.

\section{Conclusions}

Lung functions decrement was established in linear regression for $\mathrm{FEV}_{1}$ and $\mathrm{FEV}_{1} / \mathrm{FVC}$ respectively although 
not statistically significant. It is suggested that a longer follow-up study is required to better assess the individual effects on lung function systems and the incidence of respiratory diseases among welders. It shows that the used of respiratory questionnaires (ATS-DLD-78A) is an effective tool in the diagnosis of respiratory symptoms among welders as these symptoms are one of the dominant predictors of obstructive and restrictive lung function independent of welding exposure (year) and risk of smoking. Despite, the findings also show that workers exposed to welding fumes had exceeded the threshold regulatory limits set by Department of Occupational Safety and Health (DOSH), Malaysia for all traced metal fumes apart from aluminium. This study had revealed a strong correlation $(\mathrm{p}<0.05)$ between chromium, manganese, nickel, copper and aluminium in toenails and this suggests that toenail metals shared similar exposure route of the anthropogenic source of activity. This study validated that toenail is a reliable biomarker of metalworkplace pollution and suitable for acquiring chronological information of welding fumes exposure. Despite the fact that there is a limitation in this study due to a small number of respondents, this research highlighted several courses of action and approach needed to tackle the issue of welding fumes exposure towards welders. Therefore, further research with larger sample size for better representation would be of great help for a more conducive work environment especially related to safety and health aspects in line with the rapid growth of automotive sectors in Pahang, Malaysia.

\section{Declaration}

The authors firmly declare that there are no conflicts of interest related to this work. This research has the permission from the respondents also the approval of IIUM Research Ethics Committee (IREC) that operates in according to the Declaration of Helsinki, International Conference on Harmonization Good Clinical Practice Guidelines (ICH-GCP), Malaysia Good Clinical Practice Guidelines and Council for International Organizations of Medical Sciences (CIOMS) International Ethical Guidelines.

\section{Acknowledgement}

We are thankful to all participant involved from Malaysian automotive welder at Pekan, Pahang for an endless support and cooperation during the research study. We would also like to acknowledge Dr Abdul Halim Abdullah, Dr Nor Kamisah Abdul Hamid and Dr Ahmad Fauzan Zainal Bakri for their assistance in reviewing the spirometry reports and validated the amendment of a respiratory questionnaire for quality assurance. This work was financially supported by the Fundamental Research Grant Scheme (FRGS) vote 1539 under the Malaysian Ministry of Education and Universiti Tun Hussein Onn Malaysia.

\section{References}

[1] A. Lim, 'Holistic Growth for Automotive Industry in 2017 - Malaysia Automotive Institute (MAI)', 2017.

[2] G. Buonanno, L. Morawska, and L. Stabile, "Exposure to welding particles in automotive plants," Journal of Aerosol Science, vol. 42, no. 5, pp. 295-304, 2011.

[3] S. A. Meo, M. A. Azeem, and M. M. Subhan, "Lung function in Pakistani welding workers," $J$ Occup Environ Med, vol. 45, no. 10, pp. 1068-73, Oct 2003.

[4] A. N. Norali, Abdullah, A.H., Zakaria, Z., Rahim, N.A., Nataraj, S.K., "Human Breathing Classification Using Electromyography Signal with Features Based on Mel-Frequency Cepstral Coefficients," International Journal of Integrated Engineering, vol. 9, no. 4, pp. 85-92, 2017.

[5] OSHA Fact Sheet, 'Controlling Hazardous Fume and Gases during Welding', U.S. Department of Labor, 2013. [Online]. Available: https://www.osha.gov/Publications/OSHA_FS3647_Welding.pdf.

[6] M. A. Balkhyour and M. K. Goknil, "Total fume and metal concentrations during welding in selected factories in Jeddah, Saudi Arabia," Int J Environ Res Public Health, vol. 7, no. 7, pp. 2978-87, Jul 2010.

[7] J. M. Antonini, M. D. Taylor, A. T. Zimmer, and J. R. Roberts, 'Pulmonary responses to welding fumes: role of metal constituents', J. Toxicol. Environ. Health. A, vol. 67, no. 3, pp. 233-249, 2004.

[8] L. P. Singh, A. Bhardwaj, and K. K. Deepak, "Occupational Exposure to Respirable Suspended Particulate Matter and Lung Functions Deterioration of Steel Workers: An Exploratory Study in India," ISRN Public Health, vol. 2013, pp. 1-8, 2013.

[9] P. Kauppi, M. Järvelä, T. Tuomi, R. Luukkonen, T. Lindholm, R. Nieminen, E. Moilanen, and T. Hannu, 'Systemic inflammatory responses following welding inhalation challenge test', Toxicol Reports, vol. 2, pp. 357-364, 2015.

[10] M. El-Zein, J.-L. Malo, C. Infante-Rivard, and D. Gautrin, 'Prevalence and association of welding related systemic and respiratory symptoms in welders', Occup Environ Med, vol. 60, no. 9, pp. 655-661, 2003.

[11] J. P. Goulle et al., "Application of Inductively Coupled Plasma Mass Spectrometry Multielement Analysis in Fingernail and Toenail as a Biomarker of Metal Exposure," Journal of Analytical Toxicology, vol. 33, no. 2, pp. 92-98, 2009.

[12] N. H. Ab Razak, S. M. Praveena, A. Z. Aris, and Z. Hashim, 'Drinking water studies: A review on heavy metal, application of biomarker and health risk assessment (a special focus in Malaysia)', $J$ Epidemiol Glob Health, vol. 5, no. 4, pp. 297310, 2015. 
[13] H. Hassani, F. Golbabaei, H. Shirkhanloo and M. Tehrani-Doust, "Relations of biomarkers of manganese exposure and neuropsychological effects among welders and ferroalloy smelters", Industrial Health, vol. 54, no. 1, pp. 79-86, 2016.

[14] H. Backman, B. Eriksson, L. Hedman, C. Stridsman, S.-A. Jansson, A. Sovijärvi, A. Lindberg, E. Rönmark, and B. Lundbäck, 'Restrictive spirometric pattern in the general adult population: Methods of defining the condition and consequences on prevalence', Respir Med, vol. 120, pp. 116-123, Nov. 2016.

[15] M. R. Miller, J. Hankinson, V. Brusasco, F. Burgos, R. Casaburi, A. Coates, R. Crapo, P. Enright, C. P. M. van der Grinten, P. Gustafsson, R. Jensen, D. C. Johnson, N. MacIntrye, R. McKay, D. Navajas, O. F. Pedersen, R. Pellegrino, G. Viegi, and J. Wagner, 'Standardisation of spirometry', Eu. Respir J, vol. 26, no. 2, pp. 319-338, Aug. 2005.

[16] M. R. Miller, R. Crapo, J. Hankinson, V. Brusasco, F. Burgos, R. Casaburi, A. Coates, P. Enright, C. P. M. van der Grinten, P. Gustafsson, R. Jensen, D. C. Johnson, N. MacIntyre, R. McKay, D. Navajas, O. F. Pedersen, R. Pellegrino, G. Viegi, and J. Wanger, 'General considerations for lung function testing', Eur Respir J, vol. 26, no. 1, pp. 153-161, Jul. 2005.

[17] J. T. C. Li and E. J. O'Connell, 'Clinical Evaluation of Asthma', Ann Allergy Asthma Immunol, vol. 76, no. 1, pp. 1-15, Jan. 1996.

[18] N. S. Elshaer, N. M. T. Foda, H. S. Kassem, M. W. Ayaad, and D. S. Meleis, 'Bronchial asthma among workers in Alexandria and its association with occupation, eosinophil count, total serum immunoglobulin $\mathrm{E}$ antibodies, and glutathione Stransferase genes polymorphism', Alexandria $J$ Med, vol. 47, no. 1, pp. 53-65, Mar. 2011.

[19] L. M. Bradshaw, D. Fishwick, T. Slater, and N. Pearce, 'Chronic bronchitis, work related respiratory symptoms, and pulmonary function in welders in New Zealand', Occup Environ Med, vol. 55, no. 3, pp. 150-154, 1998.

[20] Tim Pneumobile Project Indonesia, 'Nilai normal faal paru Indonesia (Normal Indonesian lung function values)'. 1992.

[21] S. F. Z. Bakri, A. Hariri, N. F. Ma'arop, and N. S. A. W. Hussin, "Toenail as Non-invasive Biomarker in Metal Toxicity Measurement of Welding Fumes Exposure - A Review," IOP Conference Series: Materials Science and Engineering, vol. 165, 2017.

[22] M. L. Kile, E. A. Houseman, C. V Breton, Q. Quamruzzaman, M. Rahman, G. Mahiuddin, and D. C. Christiani, 'Association between total ingested arsenic and toenail arsenic concentrations.', J Environ Sci Health A Tox Hazard Subst Environ Eng, vol. 42, no. 12, pp. 1827-34, 2007.

[23] A. P. Sanders, S. K. Miller, V. Nguyen, J. B.
Kotch, and R. C. Fry, 'Toxic metal levels in children residing in a smelting craft village in Vietnam: a pilot biomonitoring study.', $B M C$ Public Health, vol. 14, no. 1, p. 114, 2014.

[24] U. Kucuk, M. Eyuboglu, H. O. Kucuk, and G. Degirmencioglu, 'Importance of using proper post hoc test with ANOVA.', Int J Cardiol, vol. 209, p. 346, Apr. 2016.

[25] P. C. Austin and E. W. Steyerberg, 'The number of subjects per variable required in linear regression analyses', J Clin Epidemiol, vol. 68, no. 6, pp. 627-636, 2015.

[26] I. N. Abbasi, A. Ahsan, and A. A. Nafees, 'Correlation of respiratory symptoms and spirometric lung patterns in a rural community setting, Sindh, Pakistan: a cross sectional survey', BMC Pulm Med, vol. 12, no. 1, p. 81, 2012.

[27] S. M. Hasnain, M. Khan, A. Saleem, and M. A. Waqar, 'Prevalence of asthma and allergic rhinitis among school children of Karachi, Pakistan, 2007.', J Asthma, vol. 46, no. 1, pp. 86-90, 2009.

[28] A. Hariri, N. A. Paiman, A. M. Leman, and M. Z. Yusof, 'Respiratory Effects from Welding Fumes in Automotive Industries in Malaysia', $A d v$ Environ Biol, vol. 8, no. 15, pp. 41-44, 2014.

[29] A. Hariri, M. Z. M. Yusof, and N. A. Paiman, 'Lung Functions of Welders in Three Automotive Related Industries in Malaysia', J Ind Intell Inf, vol. 3, no. 1, pp. 15-19, 2015.

[30] J.-C. J. Luo, K.-H. Hsu, and W.-S. Shen, 'Pulmonary function abnormalities and airway irritation symptoms of metal fumes exposure on automobile spot welders.', Am J Ind Med, vol. 49, no. 6, pp. 407-16, Jun. 2006.

[31] K. de Jong, H. M. Boezen, H. Kromhout, R. Vermeulen, D. S. Postma, and J. M. Vonk, 'Association of Occupational Pesticide Exposure With Accelerated Longitudinal Decline in Lung Function', Am J Epidemiol, vol. 179, no. 11, pp. 1323-1330, Jun. 2014.

[32] A. Skelly, 'Probability, proof, and clinical significance', Evid Based Spine Care J, vol. 2, no. 4, pp. 9-11, Nov. 2011.

[33] T. To, S. Stanojevic, G. Moores, A. S. Gershon, E. D. Bateman, A. A. Cruz, and L.-P. Boulet, 'Global asthma prevalence in adults: findings from the cross-sectional world health survey', BMC Public Health, vol. 12, no. 1, p. 204, 2012.

[34] L. Hartmann, M. Bauer, J. Bertram, M. Gube, K. Lenz, U. Reisgen, T. Schettgen, T. Kraus, and P. Brand, 'Assessment of the biological effects of welding fumes emitted from metal inert gas welding processes of aluminium and zinc-plated materials in humans', Int J Hyg Environ Health, vol. 217, no. 2-3, pp. 160-168, 2014.

[35] K. Torén, J. Brisman, and B. Järvholm, 'Asthma and asthma-like symptoms in adults assessed by questionnaires. A literature review.', Chest, vol. 104, no. 2, pp. 600-8, Aug. 1993.

[36] A. Hariri, A. M. Leman, M. Z. M. Yusof, N. A. 
Paiman, and N. M. Noor, 'Preliminary Measurement of Welding Fumes in Automotive Plants', Int J Environ Sci Dev, vol. 3, no. 2, pp. 146-151, 2012.

[37] N. Abdull, N. Wahida, M. Hassan, and A. R. Ismail, 'Heavy metal emitting from welding fumes in automotive industry', Int $J$ Curr Res Acad Rev, vol. 2, no. 2, pp. 148-156, 2015.

[38] K. Asaduzzaman, M. U. Khandaker, N. A. Binti Baharudin, Y. B. M. Amin, M. S. Farook, D. A. Bradley, and O. Mahmoud, 'Heavy metals in human teeth dentine: A bio-indicator of metals exposure and environmental pollution', Chemosphere, vol. 176, pp. 221-230, Jun. 2017.

[39] W. J. Mok, S. Senoo, T. Itoh, Y. Tsukamasa, K. Kawasaki, and M. Ando, 'Assessment of concentrations of toxic elements in aquaculture food products in Malaysia', Food Chem, vol. 133, no. 4, pp. 1326-1332, Aug. 2012.

[40] M. L. Kile, E. A. Houseman, E. Rodrigues, T. J. Smith, Q. Quamruzzaman, M. Rahman, G. Mahiuddin, L. Su, and D. C. Christiani, 'Toenail arsenic concentrations, GSTT1 gene polymorphisms, and arsenic exposure from drinking water', Cancer Epidemiol Biomarkers Prev, vol. 14, no. 10, pp. 2419-2426, 2005.

[41] P. Kakkar and F. N. Jaffery, 'Biological markers for metal toxicity', Environmental Toxicology and Pharmacology, vol. 19, no. 2. pp. 335-349, 2005.

[42] T. R. McClintock, Y. Chen, F. Parvez, D. V. Makarov, W. Ge, T. Islam, A. Ahmed, M. Rakibuz-Zaman, R. Hasan, G. Sarwar, V. Slavkovich, M. A. Bjurlin, J. H. Graziano, and H. Ahsan, 'Association between arsenic exposure from drinking water and hematuria: Results from the Health Effects of Arsenic Longitudinal Study', Toxicol Appl Pharmacol, vol. 276, no. 1, pp. 21-27, Apr. 2014.

[43] G. Samanta, R. Sharma, T. Roychowdhury, and D. Chakraborti, 'Arsenic and other elements in hair, nails, and skin-scales of arsenic victims in West Bengal, India', Sci Total Environ, vol. 326, no. 1-3, pp. 33-47, Jun. 2004.

[44] T. Weiss, B. Pesch, A. Lotz, E. Gutwinski, R. Van Gelder, E. Punkenburg, B. Kendzia, K. Gawrych, M. Lehnert, E. Heinze, A. Hartwig, H. U. Käfferlein, J.-U. Hahn, and T. Brüning, 'Levels and predictors of airborne and internal exposure to chromium and nickel among welders-Results of the WELDOX study', Int $J$ Hyg Environ Health, vol. 216, no. 2, pp. 175183, Mar. 2013.

[45] P. C. Zeidler-Erdely, T. G. Meighan, A. Erdely, L. a Battelli, M. L. Kashon, M. Keane, and J. M. Antonini, 'Lung tumor promotion by chromiumcontaining welding particulate matter in a mouse model.', Part Fibre Toxicol, vol. 10, no. 1, p. 45, 2013.

[46] P. Tchounwou, C. Yedjou, A. Patlolla and D.
Sutton, "Heavy Metal Toxicity and the Environment", Experientia Supplementum, pp. 133-164, 2012.

[47] S. L. O’Neal and W. Zheng, 'Manganese Toxicity Upon Overexposure: a Decade in Review', Curr Environ Heal Reports, vol. 2, no. 3, pp. 315-328, Sep. 2015.

[48] R. E. Korczynski, 'Occupational health concerns in the welding industry.', Appl Occup Environ Hyg, vol. 15, no. 12, pp. 936-45, Dec. 2000.

[49] J. Crossgrove and W. Zheng, 'Manganese toxicity upon overexposure.', NMR Biomed, vol. 17, no. 8, pp. 544-53, Dec. 2004.

[50] W. Laohaudomchok, X. Lin, R. F. Herrick, S. C. Fang, J. M. Cavallari, D. C. Christiani, and M. G. Weisskopf, 'Toenail, Blood, and Urine as Biomarkers of Manganese Exposure', J Occup Environ Med, vol. 53, no. 5, pp. 506-510, May 2011.

[51] E. G. Rodrigues, M. Kile, C. Dobson, C. Amarasiriwardena, Q. Quamruzzaman, M. Rahman, M. Golam, and D. C. Christiani, 'Maternal-infant biomarkers of prenatal exposure to arsenic and manganese', J Expo Sci Environ Epidemiol, vol. 25, no. 6, pp. 639-648, Nov. 2015.

[52] P. Chanpiwat, S. Himeno, and S. Sthiannopkao, 'Arsenic and Other Metals' Presence in Biomarkers of Cambodians in Arsenic Contaminated Areas', Int J Environ Res Public Health, vol. 12, no. 11, pp. 14285-14300, Nov. 2015.

[53] W. J. Chen, R. J. Monnat, M. Chen, and N. K. Mottet, 'Aluminum induced pulmonary granulomatosis.', Hum Pathol, vol. 9, no. 6, pp. 705-11, Nov. 1978.

[54] S. Polizzi, E. Pira, M. Ferrara, M. Bugiani, A. Papaleo, R. Albera, and S. Palmi, 'Neurotoxic Effects of Aluminium Among Foundry Workers and Alzheimer's Disease', Neurotoxicology, vol. 23, no. 6, pp. 761-774, Dec. 2002.

[55] D. Krewski, R. a Yokel, E. Nieboer, D. Borchelt, J. Cohen, J. Harry, S. Kacew, J. Lindsay, A. M. Mahfouz, and V. Rondeau, 'Human Health Risk Assessment for Aluminium, Aluminium Oxide, and Aluminium Hydroxide', J Toxicol Environ Heal Part B, vol. 10, no. sup1, pp. 1-269, Nov. 2007.

[56] M. Hirata-Koizumi, S. Fujii, A. Ono, A. Hirose, T. Imai, K. Ogawa, M. Ema, and A. Nishikawa, 'Two-generation reproductive toxicity study of aluminium sulfate in rats', Reprod Toxicol, vol. 31, no. 2, pp. 219-230, Feb. 2011.

[57] A. R. Nurdin, Sameer, A., Badarulzaman, N.A., "A Short Review on Aluminium Smelting and Its Future Prospect in Malaysia Metal Industries," International Journal of Integrated Engineering, vol. 7, no. 2, pp. 1-4, 2015.

[58] R. Grashow, J. Zhang, S. C. Fang, M. G. Weisskopf, D. C. Christiani, and J. M. Cavallari, 
'Toenail metal concentration as a biomarker of occupational welding fume exposure.', J Occup Environ Hyg, vol. 11, no. 6, pp. 397-405, Dec. 2014.

[59] J. Y. Y. Wong, S. C. Fang, R. Grashow, T. Fan, and D. C. Christiani, 'The Relationship Between Occupational Metal Exposure and Arterial Compliance', J Occup Environ Med, vol. 57, no. 4, pp. 355-360, Apr. 2015.

[60] K. Sriram, G. X. Lin, A. M. Jefferson, J. R. Roberts, R. N. Andrews, M. L. Kashon, and J. M. Antonini, 'Manganese accumulation in nail clippings as a biomarker of welding fume exposure and neurotoxicity', Toxicology, vol. 291, no. 1-3, pp. 73-82, Jan. 2012.

[61] F. I. Abdulrahman, J. C. Akan, Z. M. Chellube, and M. Waziri, 'Levels of Heavy Metals in Human Hair and Nail Samples from Maiduguri Metropolis, Borno State, Nigeria', World Environ, vol. 2, no. 4, pp. 81-89, Aug. 2012.

[62] P. M. Lind, L. Olsén, and L. Lind, 'Circulating levels of metals are related to carotid atherosclerosis in elderly', Sci Total Environ, vol. 416, pp. 80-88, Feb. 2012.
[63] D. Schaumlöffel, 'Nickel species: analysis and toxic effects.', J Trace Elem Med Biol, vol. 26, no. 1, pp. 1-6, Jan. 2012.

[64] T. P. Coogan, D. M. Latta, E. T. Snow, and M. Costa, 'Toxicity and carcinogenicity of nickel compounds.', Crit Rev Toxicol, vol. 19, no. 4, pp. 341-84, 1989.

[65] K. K. Das, S. N. Das, and S. a Dhundasi, 'Nickel, its adverse health effects \& oxidative stress.', Indian J Med Res, vol. 128, no. 4, pp. 412-25, Oct. 2008.

[66] A. Modrykamien, H. Christie, C. Farver, and R. W. Ashton, 'A 38-year-old welder with dyspnea and iron overload.', Chest, vol. 136, no. 1, pp. 310-313, Jul. 2009.

[67] E. S. Gurzau, C. Neagu, and A. E. Gurzau, Essential metals - case study on iron, Ecotoxicol Environ Saf, vol. 56, no. 1, pp. 190-200, Sep. 2003.

[68] ATSDR, Public Health Statement for Cobal', Agency for Toxic Substances and Disease Registry, 2004. [Online]. Available: https://www.atsdr.cdc.gov/phs/phs.asp?id=371\&ti $\mathrm{d}=64$. [Accessed: 04-Aug-2017]. 